\title{
Accelerated senescence of human peritoneal mesothelial cells exposed to high glucose: the role of TGF- $\beta 1$
}

\author{
Krzysztof Książek', Katarzyna Korybalska ${ }^{1}$, Achim Jörres ${ }^{2}$ and Janusz Witowski ${ }^{1,2}$
}

Cellular senescence can be activated in response to noxious environmental stimuli. A senescent-like phenotype has been detected in the peritoneal mesothelium of mice exposed to high intraperitoneal glucose. We have sought to examine whether high glucose $(\mathrm{HG})$ can induce the senescence program in human peritoneal mesothelial cells (HPMC) in vitro. Senescence of omentum-derived HPMC was induced by serial passages. Cells were cultured in media containing either $5 \mathrm{mM}$ glucose, $30 \mathrm{mM}$ glucose, or $5 \mathrm{mM}$ glucose and $25 \mathrm{mM}$ mannitol (M) for osmotic control. Compared with HPMC cultured in low glucose, the growth rate of cells exposed to HG was significantly decreased so that the cells reached fewer population doublings before entering senescence. Exposure to HG led to increased expression of senescence-associated $\beta$-galactosidase (SA- $\beta$-Gal) and of the cell cycle inhibitors $\mathrm{p} 21^{\text {Waf1 }}$ and $\mathrm{p} 27^{\mathrm{Kip} 1}$. Late-passage HPMC exposed to HG displayed marked hypertrophy and released increased amounts of fibronectin and TGF- $\beta 1$. These effects were absent from HPMC treated with equimolar M. Exposure of early-passage HPMC to exogenous recombinant TGF- $\beta 1$ induced a senescence marker SA- $\beta$-Gal in a dose-dependent manner and mimicked other senescence-associated alterations induced by HG. The addition of anti-TGF- $\beta 1$ neutralizing antibody partially reduced the activation of HG-induced SA- $\beta$-Gal. These results indicate that chronic exposure to elevated glucose may result in TGF- $\beta 1$-mediated accelerated senescence of HPMC in vitro, which may hypothetically contribute to the peritoneal membrane dysfunction during peritoneal dialysis in vivo.

Laboratory Investigation (2007) 87, 345-356. doi:10.1038/labinvest.3700519; published online 12 February 2007

KEYWORDS: cell senescence; glucose; mesothelial cells; peritoneal dialysis; TGF- $\beta$

There are growing concerns about the long-term impact of peritoneal dialysis fluids (PDF) on the integrity of peritoneal membrane. It is believed that some alterations in peritoneal structure and function, which develop in patients undergoing continuous ambulatory peritoneal dialysis (CAPD), may result from the prolonged exposure to bioincompatible PDF. The improvements in manufacturing of PDF reduced adverse effects related to low $\mathrm{pH}$ and glucose degradation products. However, glucose itself seem to have no realistic alternative as the main osmotic agent for PDF. And paradoxically, glucose is viewed as being largely responsible for unfavorable effects of PDF. This assumption is based on the fact that the alterations seen in the peritoneum of dialyzed patients often resemble those seen in diabetics and include thickening of basement membranes, vasculopathy, and accumulation of advanced glycation end-products. ${ }^{1-3}$
The peritoneal mesothelium plays a pivotal role in controlling the peritoneal homeostasis. Therefore, the detrimental impact of high glucose (HG) on mesothelial cells may contribute to the peritoneal membrane dysfunction during dialysis. In a series of experiments, Gotloib et $a l^{4,5}$ analyzed the imprints of the mesothelium obtained from mice exposed chronically to glucose-containing PDF. They found a significant increase in both the average size of mesothelial cell and the prevalence of very large cells, which together resulted in reduced density of the mesothelial monolayer. Moreover, the mitotic index of these cells was markedly decreased. The authors noticed that all these alterations were very similar to those characterizing the population of senescent cells.

It is now recognized that cell senescence may occur not only as a result of critical telomere dysfunction, but also in response to a number of environmental stresses (reviewed by

\footnotetext{
'Department of Pathophysiology, University Medical School, Poznań, Poland and ${ }^{2}$ Department of Nephrology and Medical Intensive Care, Universitätsmedizin Charité, Campus Virchow-Klinikum, Berlin, Germany

Correspondence: Dr J Witowski, MD, Department of Pathophysiology, University Medical School, Święcickiego 6, 60-781 Poznań, Poland. E-mail: jwitow@amp.edu.pl Received 25 May 2006; revised 30 November 2006; accepted 4 December 2006
} 
Ben Porath and Weinberg ${ }^{6}$ ). Although activated through a different pathway, cells undergoing stress-induced premature senescence acquire all typical features of senescence: growth arrest, chromatin silencing, different gene expression patterns, and greatly enlarged morphology. We have recently examined the senescent phenotype of human peritoneal mesothelial cells (HPMC). ${ }^{7}$ It appears that HPMC in culture enter senescence relatively early, losing rapidly the proliferative capacity but increasing significantly in size.

Cellular hypertrophy is usually defined as an increase in cellular protein content but without corresponding DNA replication. It may occur when the cells synthesize proteins in preparation for cell division, but then become growth arrested at $G_{1}$ phase of the cell cycle. Although senescent cells cease to replicate, they remain metabolically active and synthesize proteins. Therefore, a distinctive feature of aged cells is hypertrophy with an accompanying increase in cell size. On the other hand, cellular hypertrophy has been associated with hyperglycemia, and as such has been extensively studied in the context of diabetic nephropathy. Many studies have demonstrated that exposure of mesangial cells to elevated glucose alters the cell cycle and metabolism in a way that may ultimately lead to cellular hypertrophy (reviewed by Shankland and Wolf, ${ }^{8}$ Wolf $^{9}$ ). During CAPD the peritoneal mesothelium is exposed to glucose at concentrations much higher that those seen in diabetes. Therefore, a similar problem may arise in the peritoneum.

Given that hypertrophy is a hallmark of both senescent cells and cells exposed to hyperglycemia, we have sought to examine if there exists a link between HG and activation of the senescence program in peritoneal mesothelial cells. We show that chronic exposure of cultured HPMC to increased concentrations of glucose leads to accelerated development of the senescent phenotype, largely through increased generation of transforming growth factor- $\beta 1$ (TGF- $\beta 1$ ).

\section{MATERIALS AND METHODS}

Unless otherwise stated, all chemicals were purchased from Sigma-Aldrich Corp. (St Louis, MO, USA). All tissue culture plastics were from Nunc (Roskilde, Denmark).

\section{Cell Culture}

Omentum-derived human peritoneal mesothelial cells (HPMC) were isolated as detailed elsewhere. ${ }^{10}$ The specimens of omentum were obtained from consenting non-uremic and non-diabetic patients undergoing elective abdominal surgery. Cells were propagated in Earle's buffered M199 culture medium supplemented with L-glutamine $(2 \mathrm{mM})$, penicillin $(100 \mathrm{U} / \mathrm{ml})$, streptomycin $(100 \mu \mathrm{g} / \mathrm{ml})$, hydrocortisone $(0.4 \mu \mathrm{g} / \mathrm{ml})$, and $10 \% \mathrm{v} / \mathrm{v}$ fetal calf serum (Invitrogen, Karlsruhe, Germany). Cells were identified as mesothelial by their uniform cobblestone appearance at confluence and positive staining for cytoskeleton cytokeratin and mesothelial cell-specific microvilli-associated HBME-1 antigen. ${ }^{11,12}$

\section{Induction of Senescence}

Senescence was induced by serial passages, as described previously. ${ }^{7}$ Briefly, upon reaching confluence, cells from the primary culture were dislodged using a trypsin-EDTA (0.05$0.02 \%$ ) solution and seeded into a new culture flask at a density of $3 \times 10^{4} \mathrm{cells} / \mathrm{cm}^{2}$. Next passages were performed at three-day intervals with the same seeding density. The passages were carried out up to when the number of cells did not increase any further. Cells were counted using the Bürker chamber, and the number of population doublings (PD) was calculated as follows: $\mathrm{PD}=\log _{2}\left(C_{\mathrm{t}} / C_{\mathrm{o}}\right)$, where $C_{\mathrm{o}}$ is the number of cells inoculated, and $C_{\mathrm{t}}$ is the number of cells harvested. HPMC derived from the primary culture were considered to be at $\mathrm{PD}=0$. During subsequent passages, no correction was made for cells that failed to attach or reinitiate growth. As HPMC lines established from different donors show large variability and enter senescence after different number of passages, ${ }^{7}$ the cells were examined at their first and last passages, designated as 'early' and 'late', respectively. This approach enabled comparisons between the donors.

\section{Experimental Conditions}

HPMC were cultured into senescence in standard medium containing $5 \mathrm{mM}$ glucose (NG, normal glucose). In the test group, the medium was supplemented with additional $25 \mathrm{mM}$ glucose to reach the final concentration of $30 \mathrm{mM}$ (HG). To normalize for the resulting hyperosmolality, the parallel cultures were maintained in the presence of $5 \mathrm{mM}$ glucose and $25 \mathrm{mM}$ mannitol (M). When cells from one experimental group ceased to proliferate and could not be passed further, the corresponding cultures were also terminated so that all groups were assessed at the same time points.

In a separate series of experiments the early-passage HPMC were cultured in standard control medium supplemented with recombinant human TGF- $\beta 1$ (R\&D Systems, Wiesbaden, Germany). In order to determine whether the effects of HG were mediated by TGF- $\beta 1$, HPMC were cultured in the presence of either neutralizing anti-TGF- $\beta 1$ antibody (R\&D Systems, Cat. No AF-101-NA) or control chicken IgY (R\&D Systems, Cat. No AB-101-C). The antibodies were applied at a concentration of $400 \mathrm{ng} / \mathrm{ml}$, as demonstrated by Tremain et al. ${ }^{13}$ The media with antibodies were changed every 2 days.

\section{Detection of SA- $\beta$-Gal}

The presence of senescence-associated $\beta$-galactosidase (SA- $\beta$ Gal) was visualized according to Dimri et al. ${ }^{14}$ The technique was applied to HPMC essentially as described previously. ${ }^{7}$ In addition, SA- $\beta$-Gal expression was quantified by measuring the rate of conversion of 4-methylumbelliferyl- $\beta$-D-galactopiranose to 4-methylumbelliferone at $\mathrm{pH} 6.0$, as described by Gary and Kindell. ${ }^{15}$ 


\section{Detection of p21 WAF1}

Expression of $\mathrm{p} 21^{\mathrm{WAF} 1}$ was assessed with the use of specific p2 $1^{\text {WAF1 }}$ immunoassay kit (Calbiochem ${ }^{\circledR}$, Merck Biosciences, Darmstadt, Germany). Cell extracts were prepared and the assay was performed according to the protocols provided by the manufacturer. One unit of $\mathrm{p} 21^{\mathrm{WAFl}}(1 \mathrm{U} / \mathrm{ml})$ was defined as the amount of $\mathrm{p} 21^{\mathrm{WAF} 1}$ originating from $2.7 \times 10^{5}$ human breast adenocarcinoma cells (of the MCF7 line) harvested in a standardized manner. The results were normalized per number of cells used to prepare cell extracts of equal protein content.

\section{Detection of $\mathbf{p 2} 7^{\mathrm{Kip} 1}$}

Expression of $\mathrm{p} 27^{\mathrm{Kip} 1}$ was assessed by immunocytochemistry. HPMC were cultured in Lab-Tek Chamber Slides (Nunc), fixed with $70 \%$ ethanol and incubated with a monoclonal anti-p27 ${ }^{\text {Kip } 1}$ antibody (Dako, Glostrup, Denmark). Bound antibodies were visualized by immunoperoxidase staining performed with the EnVision ${ }^{+}$System (Dako) according to manufacturer's instructions.

\section{Morphometric Evaluation}

The slides were initially inspected at low magnification to identify the areas free of any damage. Two randomly selected regions were then viewed under higher magnification and 500 cells were counted by moving from left to right and from top to bottom. The morphometric analysis was performed on digitalized microscopic images (Nikon Eclipse E-400, Tokyo, Japan) by using Screen Measurement 4.21 software (Laboratory Imaging, Prague, Czech Republic).

\section{Assessment of Cellular Hypertrophy}

One hundred thousand cells from early and late passages were solubilized with $0.1 \% \mathrm{NaOH}$. Protein concentration in cell lysates was determined with the Bradford method using Protein Assay Dye Reagent (Bio-Rad, Munich, Germany). The ratio of total cell protein to the corresponding cell number was used as an indicator of cellular hypertrophy.

\section{Measurement of TGF- $\beta 1$ and Fibronectin Release}

The concentrations of TGF- $\beta 1$ and fibronectin in culture supernates were measured with enzyme-linked immunoassays. In the TGF- $\beta 1$ assay, the extracellular domain of human TGF- $\beta$ type II receptor fused to the Fc region of human IgG served as a capture, and the biotinylated antiTGF- $\beta$ antibody was used for detection (all reagents from $\mathrm{R} \& \mathrm{D}$ Systems). The assay was designed and performed as per manufacturer's instructions. TGF- $\beta 1$ levels were determined after sample activation with $1 \mathrm{~N} \mathrm{HCl}$ and subsequent neutralization with $1.2 \mathrm{~N} \mathrm{NaOH} / 0.5 \mathrm{M}$ HEPES. The immunoassay for fibronectin employed anti-human fibronectin antibodies from Dako (Hamburg, Germany) and Biogenesis (Quartett, Berlin, Germany), as described previously. ${ }^{16}$ The sensitivity of the assays was $15 \mathrm{pg} / \mathrm{ml}$ for TGF- $\beta 1$, and $0.31 \mathrm{ng} / \mathrm{ml}$ for fibronectin.

\section{$\left[^{3} \mathrm{H}\right]$-Thymidine Incorporation}

Early-passage HPMC were plated onto 48-well clusters and allowed to attach for $2 \mathrm{~h}$. Then, the cells were exposed to TGF- $\beta 1$ for $24 \mathrm{~h}$ in the presence of $\left[{ }^{3} \mathrm{H}\right]$-thymidine (as methyl- $\left[{ }^{3} \mathrm{H}\right]$-thymidine; $1 \mu \mathrm{Ci} / \mathrm{ml}$; Institute of Radioisotopes, Prague, Czech Republic). After the incubation the cells were

Table 1 Primer sequences and PCR conditions

\begin{tabular}{|c|c|c|c|c|}
\hline \multicolumn{5}{|l|}{$\beta$-Actin } \\
\hline R: 5'-TGCTCACAGGCAAGGTGTAG-3' & 204 & 30 & 55 & 18 \\
\hline F: 5'-GGCAGTGGTTGAGCCGTGGA-3' & & & & \\
\hline R: $5^{\prime}$-TGTTGGACAGCTGCTCCACCT-3' & 510 & 35 & 55 & 19 \\
\hline \multicolumn{5}{|l|}{ Fibronectin } \\
\hline \multicolumn{5}{|l|}{ F: 5'-AGCCGCCACGTGCCAGGATTAC-3' } \\
\hline \multicolumn{5}{|l|}{ F: 5'-TCTGTAGTAGAACTCGGGCAA-3' } \\
\hline R: 5'-AGTTCAAACGTGCGAGTGTC-3' & 266 & 29 & 60 & 21 \\
\hline
\end{tabular}



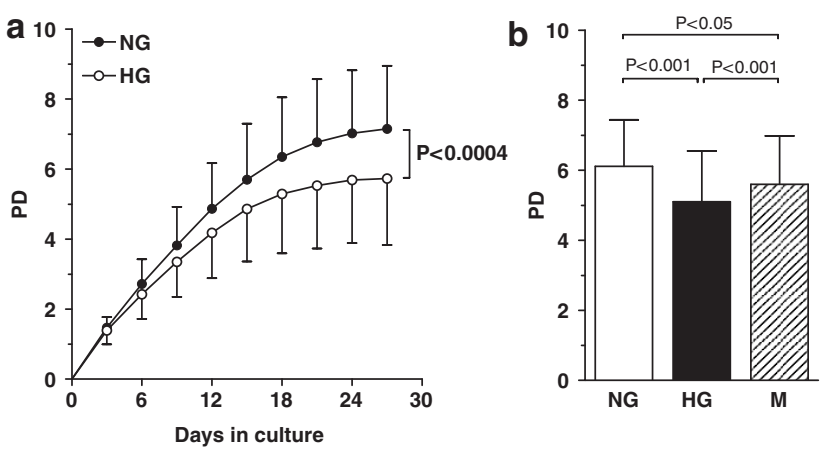

Figure 1 Effect of glucose on HPMC proliferation. Cells were grown into senescence in the presence of $N G, H G$, or equimolar $M$, as described in Materials and methods. (a) Kinetics of growth: the cumulative number of PD was assessed at each passage. The data were derived from 9 experiments with cells from different donors. The $P$-value refers to the impact of glucose on the difference between the curves as analyzed by two-way ANOVA. (b) The total number of PD achieved by HPMC grown into senescence under different conditions. The means of 11 experiments with cells from separate donors.

harvested, precipitated with $10 \%(\mathrm{w} / \mathrm{v})$ trichloroacetic acid (TCA), and dissolved in $0.1 \mathrm{~N} \mathrm{NaOH}$. The radioactivity released was measured in a beta liquid scintillation counter (Wallac, Perkin Elmer, Warsaw, Poland).

\section{$\left[{ }^{3} \mathrm{H}\right]$-Proline Incorporation}

Early-passage HPMC were plated onto 48-well plates and grown to confluence. Then, the cells were treated with TGF$\beta 1$ for $48 \mathrm{~h}$ in the presence of $\beta$-aminopropionitrile, ascorbic acid (both at $50 \mu \mathrm{g} / \mathrm{ml}$ ), and ${ }^{3} \mathrm{H}$-proline $(4 \mu \mathrm{Ci} / \mathrm{ml}$; Amersham Biosciences, Little Chalfont, UK). The cells were lysed in $\mathrm{H}_{2} \mathrm{O}$ by repeated freezing and thawing, and precipitated with $10 \%$ TCA. The precipitate was solubilized in $0.1 \mathrm{~N}$ $\mathrm{NaOH}$ and measured for radioactivity in a beta counter.

\section{Reverse Transcription-Polymerease Chain Reaction}

Total RNA from HPMC cultures was extracted with the RNA Bee (Tel-Test, Friendswood, TX, USA) and purified according to the manufacturer's protocol. RNA $(1 \mu \mathrm{g})$ was reverse transcribed into cDNA with random hexamer primers, as described elsewhere. ${ }^{17}$ Primer sequences and PCR conditions were as shown in Table 1.

\section{Statistical Analysis}

Statistical analysis was performed using a repeated measures analysis of variance with the Newman-Keuls multiple comparison post-test (GraphPad Prism ${ }^{\mathrm{TM}} 4.00$ software; GraphPad Software, San Diego, CA, USA). When appropriate, the comparisons were made with the McNemar's test (Analyse-It 1.71 software; Analyse-It Software, Leeds, UK). Results are expressed as the means \pm s.d. Differences with a $P$-value $<0.05$ were considered as statistically significant.
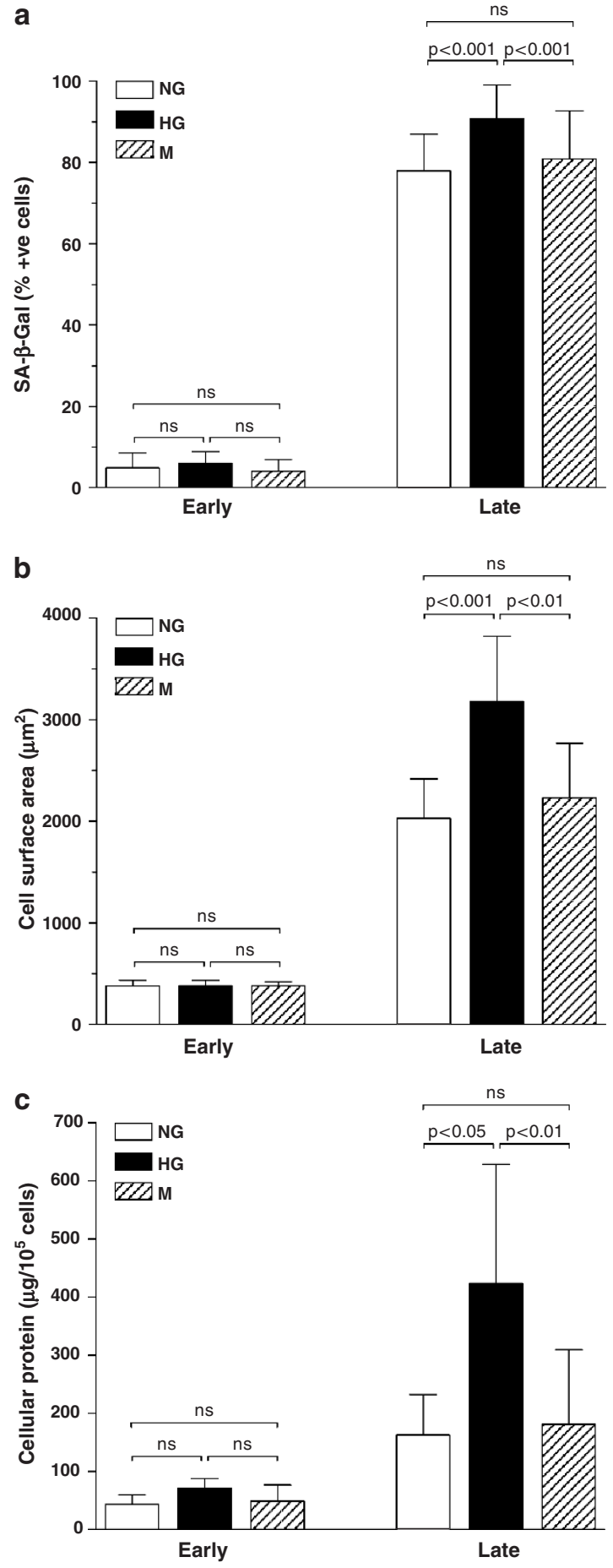

Figure 2 Effect of glucose on the features of senescence HPMC. Cells were grown into senescence in the presence of NG, HG, or equimolar M. Earlyand late-passage HPMC were assessed for the presence of SA- $\beta$-Gal (a), cell surface area (b), and cellular protein contents (c). The data were obtained from six to nine experiments with cells from separate donors.

\section{RESULTS}

HG Inhibits the Proliferation of HPMC

Continuous exposure to $\mathrm{HG}(30 \mathrm{mM})$ decreased the rate of HPMC proliferation (Figure 1a). This inhibitory effect of 
glucose was not evident at an early phase of exposure. In fact, in $35 \%$ of all cultures examined, the number of cells treated with HG increased slightly during first 3 days of incubation.
However, during the next passages the decrease in HPMC proliferation was seen consistently and became more and more pronounced. As a result, the exhaustion of the pro- a

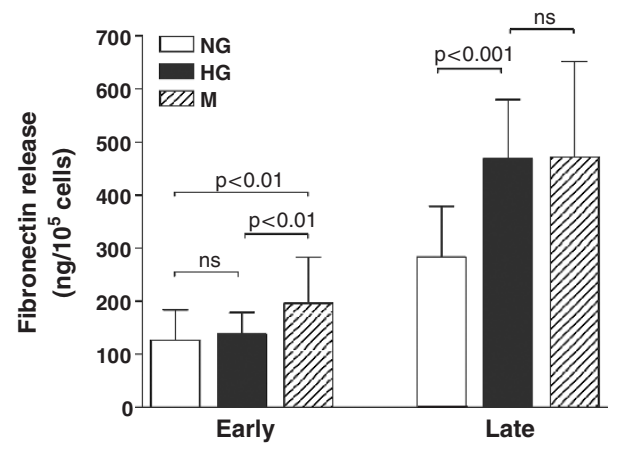

b

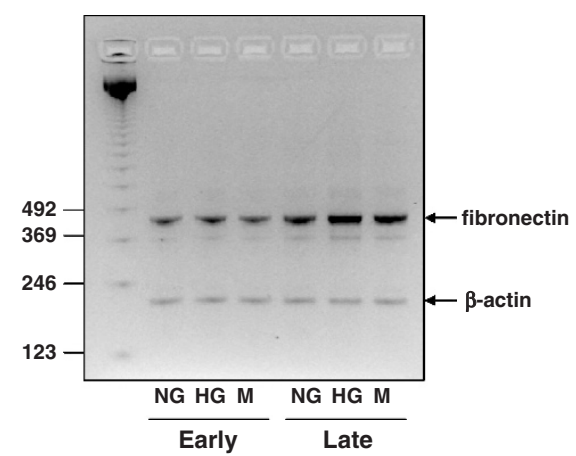

C

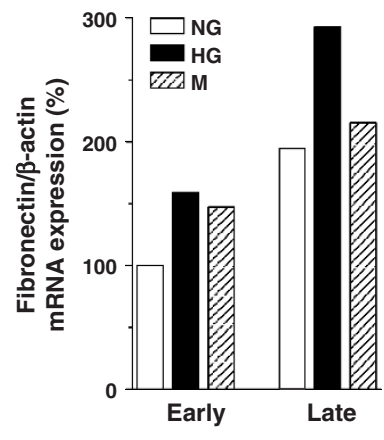

Figure 3 Effect of glucose on the production of fibronectin by senescent HPMC. Cells were grown into senescence in the presence of either NG, HG, or equimolar M. (a) The mean fibronectin release by early-and late-passage HPMC. The data derived from 10 experiments with cells from separate donors. (b) Fibronectin mRNA expression by early- and late-passage HPMC as assessed by RT-PCR; a representative experiment of 2 performed. (c) Densitometric fibronectin/ $\beta$-actin ratios were expressed as a percentage of the value characterizing early-passage control cells.

a

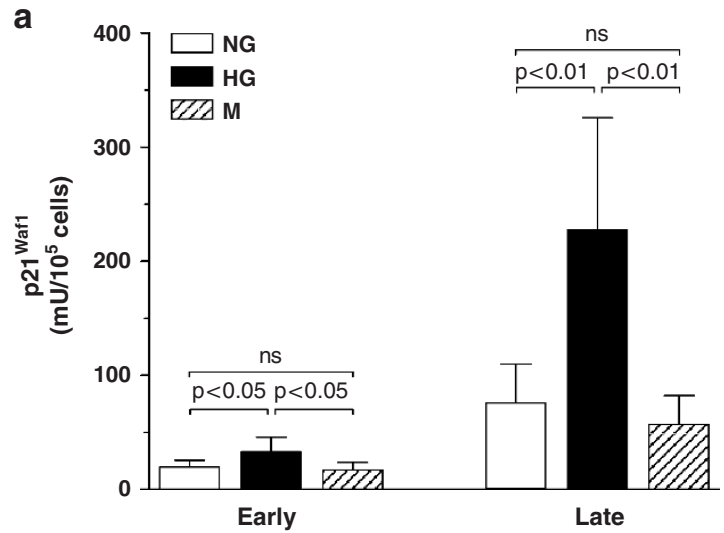

C

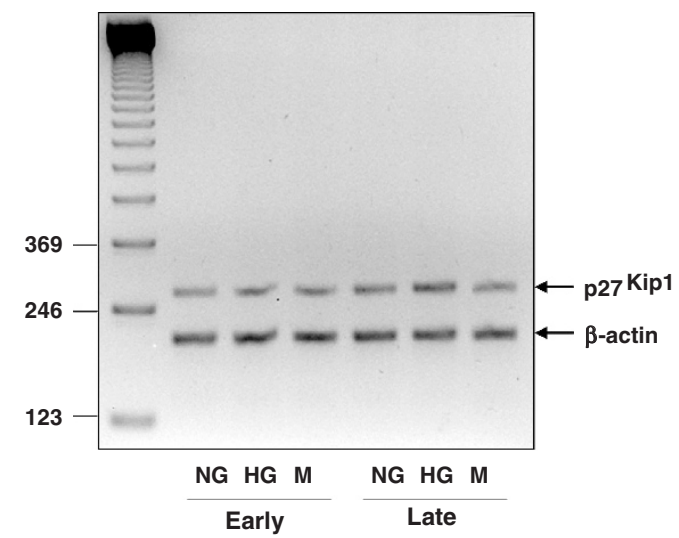

b

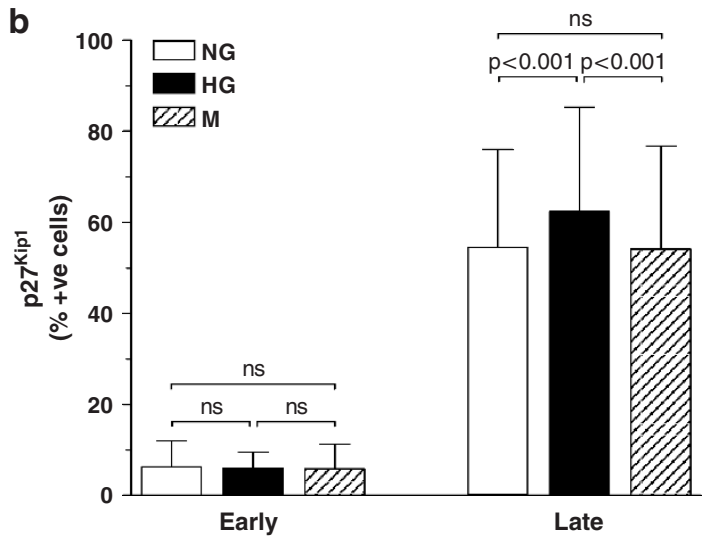

d

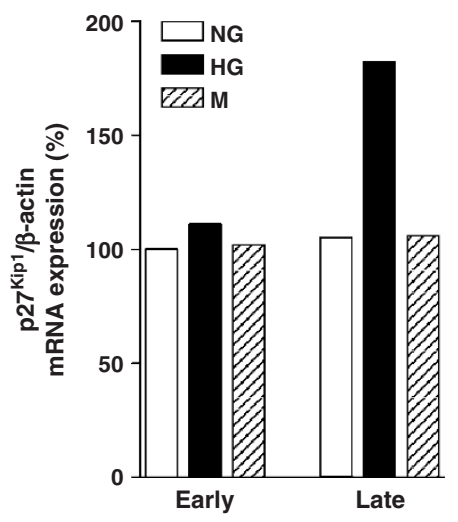

Figure 4 Effect of glucose on the expression of $\mathrm{p} 21^{\text {Waf1 }}$ and $\mathrm{p} 27^{\mathrm{Kip} 1}$ by senescent HPMC. Cells were grown into senescence in the presence of either NG, $\mathrm{HG}$, or equimolar M. (a) p21 ${ }^{\text {Waf1 }}$ activity was assessed by immunoassay in four experiments performed with cells from three different donors; (b) the percentage of cells staining positively for $\mathrm{p} 27^{\mathrm{Kip} 1}$. The results of eight independent experiments with cells from different donors. (c) $\mathrm{p} 27^{\mathrm{Kip} 1} \mathrm{mRNA}$ expression by early- and late-passage HPMC as assessed by RT-PCR; a representative experiment of two performed. (d) Densitometric $\mathrm{p} 27^{\text {Kip } 1 / \beta \text {-actin ratios }}$ were expressed as a percentage of the value characterizing early-passage control cells. 
liferation capacity of these cells occurred earlier compared to control HPMC maintained in low glucose. The two-way analysis of variance revealed that the curves describing the growth-over-time relationship for cells cultured in low and HG were significantly different $(F=13.35, P=0.0004)$.

Such an effect was less obvious in HPMC exposed to equimolar concentration of $\mathrm{M}$. These cells were losing their proliferative potential at a rate only slightly increased compared to control cells, but more slowly compared to cells exposed to HG. Consequently, M-treated cells reached only marginally fewer PD compared with the controls, but significantly more than glucose-treated HPMC (Figure 1b).

\section{HG Increases the Expression of the Senescence Marker SA- $\beta$-Gal and Augments Senescence-Associated HPMC Hypertrophy}

As demonstrated previously, ${ }^{7}$ the senescence of HPMC was associated with the appearance of the senescence marker SA- $\beta$-Gal and with the increase in cell size and cellular protein contents (Figure 2). These features of senescence were significantly more pronounced in HPMC grown in HG. The differences were not apparent in early-passage cells, but became highly significant in late-passage cells. In HGtreated cultures more than $90 \%$ of cells stained positively for SA- $\beta$-Gal, while in cells senescing under NG, this percentage at the same stage was $78 \%$. In two randomly selected cultures the expression of SA- $\beta$-Gal was also assessed at the fourth passage, which corresponded to about $50 \%$ of their lifespan in vitro. At this stage the number of senescent cells in HPMC cultures began to increase with the percentage of SA- $\beta$-Gal-positive cells already higher in cultures exposed to HG (13vs 9\%). Moreover, the size of HPMC that reached senescence in the presence of HG was increased by approximately $56 \%$ and the cellular protein content of these cells increased by $160 \%$, compared with HPMC cultured in low glucose. In contrast, in cells exposed to $\mathrm{M}$, the senescence-associated rise in SA- $\beta$-Gal expression, cell size and protein contents occurred at a rate similar to that seen in control cells.

\section{HG Increases the Expression and Release of Fibronectin by Senescent HPMC}

In control late-passage cells the expression of fibronectin mRNA and the release of protein was significantly increased compared with early-passage cells (Figure 3). This pattern was also seen in HPMC exposed to HG, however, the magnitude of the increase was significantly greater. Exposure to $\mathrm{M}$ also resulted in an augmented fibronectin release, which was seen already in early-passage cells and in senescent cells was comparable to that induced by HG.

\section{HG Increases the Expression of Cell Cycle Inhibitors p2 $1^{\text {Waf } 1}$ and p2 $7^{\text {Kip } 1}$ by Senescent HPMC}

Senescence of HPMC was associated with an almost four-fold increase in $\mathrm{p} 21^{\text {Waf1 }}$ expression, as assessed by an im- a
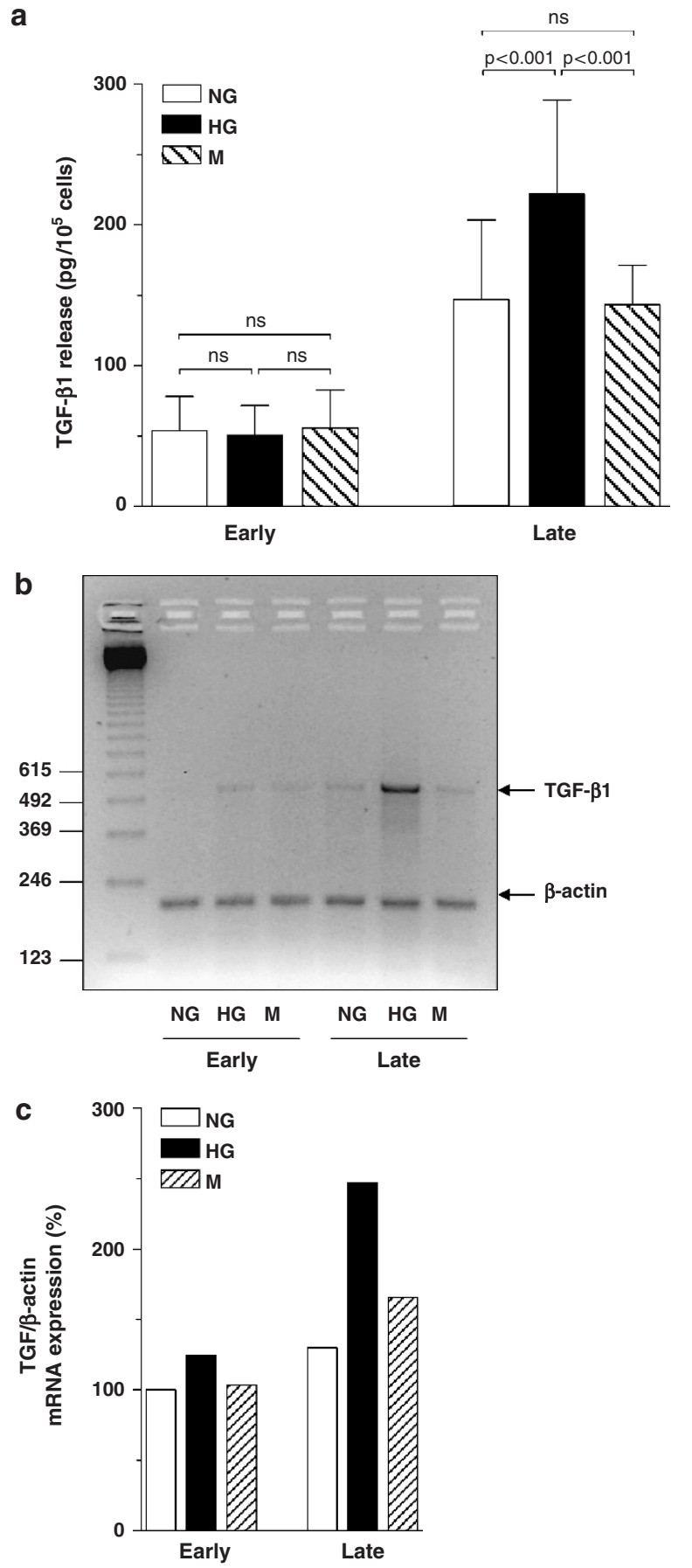

Figure 5 Effect of glucose on the expression of TGF- $\beta 1$ by senescent HPMC. Cells were grown into senescence in the presence of either NG, HG, or equimolar M. (a) The mean TGF- $\beta 1$ release by early- and late-passage HPMC. The data derived from 10 experiments with cells from separate donors. (b) TGF- $\beta 1$ mRNA expression by early- and late-passage HPMC as assessed by RT-PCR; a representative experiment of two performed. (c) Densitometric TGF- $\beta 1 / \beta$-actin ratios were expressed as a percentage of the value characterizing early-passage control cells.

munoassay (Figure 4a) and a nine-fold increase in p27 ${ }^{\text {Kip1 }}$ expression, as assessed by immunocytochemistry (Figure 4b). These effects were significantly exacerbated in cells exposed 


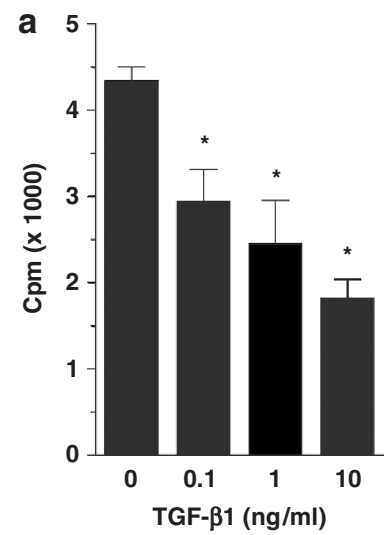

d



b

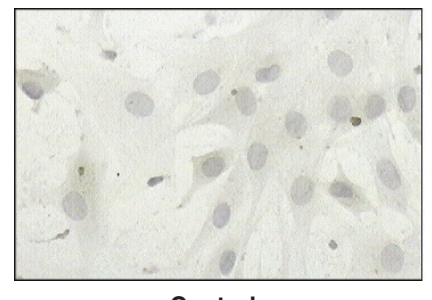

Control

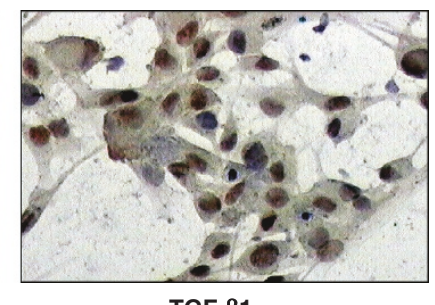

TGF- $\beta 1$
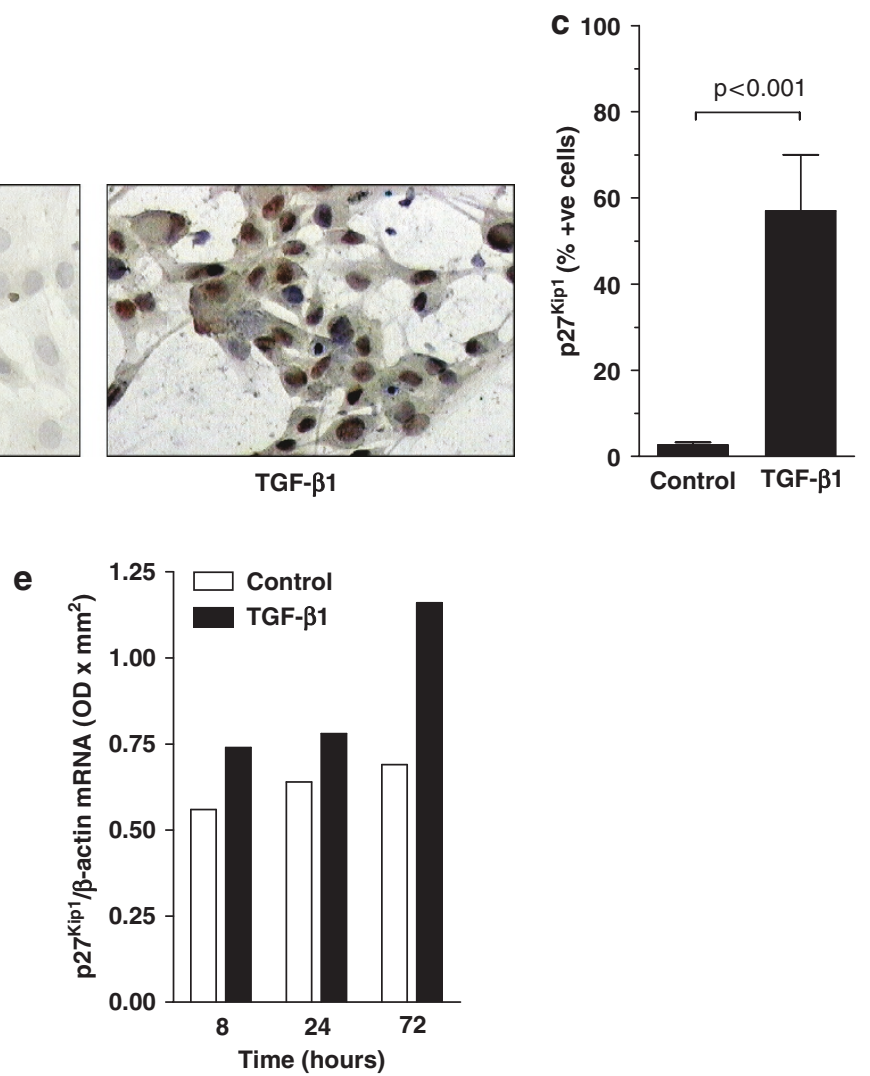

Figure 6 Effect of TGF- $\beta 1$ on HPMC growth. (a) Serum-stimulated early-passage cells were incubated with increasing doses of TGF- $\beta 1$ and the synthesis of DNA was assessed by ${ }^{3} \mathrm{H}$-thymidine incorporation. The data were derived from 3 independent experiments with the use of cells from different donors. Asterisks represent a significant difference compared with cells not exposed to TGF- $\beta 1$. (b) Serum-stimulated early-passage HPMC were treated with $1 \mathrm{ng} / \mathrm{ml}$ of TGF- $\beta 1$ for $72 \mathrm{~h}$ and then immunostained for $\mathrm{p} 27^{\mathrm{Kip} 1}$ and counterstained with Mayer's hematoxylin. Magnification $\times 100$. (c) Percentage of cells expressing $\mathrm{p} 27^{\mathrm{Kip} 1}$ after the incubation in the presence or absence of TGF- $\beta 1$. The means of three independent experiments with cells from different donors. (d) $\mathrm{p} 27^{\mathrm{Kip}}$ mRNA expression in early-passage HPMC treated with $10 \mathrm{ng} / \mathrm{ml}$ of TGF- $\beta 1$ for the time-periods indicated; a representative RT-PCR experiment of two performed. (e) Densitometric p27 Kip $/ \beta$-actin ratios were calculated for cells incubated in the presence ( $\mathbf{\square}$ ) or absence ( $\square$ ) of TGF- $\beta 1$.

to HG. Exposure to HG resulted in increased expression of p $27^{\text {Kip } 1}$ mRNA (Figure $4 \mathrm{c}-\mathrm{d}$ ), but not of p21 ${ }^{\text {Waf1 }}$ mRNA (not shown). In contrast, in cells exposed to $M$ the expression of neither $\mathrm{p} 27^{\mathrm{Kip} 1}$ nor $\mathrm{p} 21^{\text {Wafl }}$ differed significantly from that in control cells.

\section{HG Increases the Expression and Release of TGF- $\beta 1$ by Senescent HPMC}

Senescent HPMC released more TGF- $\beta 1$ compared with early-passage cells (Figure 5). Cells that reached senescence in the presence of HG secreted approximately $50 \%$ more TGF$\beta 1$ compared with sister cells cultured in NG. This rise was associated with the increased TGF- $\beta 1$ mRNA expression. Exposure to $M$ had no similar effect.

\section{Exposure to Exogenous TGF- $\beta 1$ Induces the Senescent Phenotype in Early-Passage HPMC}

In order to determine whether the effects exerted by HG could have been related to the induction of TGF- $\beta 1$, earlypassage cells were treated with exogenous recombinant human TGF- $\beta 1$ and examined for the features of senescence. Exposure of vigorously proliferating HPMC to TGF- $\beta 1$ resulted in a dose-dependent growth inhibition as measured by ${ }^{3} \mathrm{H}$-thymidine incorporation (Figure 6a). Moreover, the fraction of early-passage cells expressing p $27^{\mathrm{Kip} 1}$ increased almost up to $60 \%$ as a result of the exposure to TGF- $\beta 1$ (Figure $6 \mathrm{~b}-\mathrm{c}$ ). This effect was also associated with a timedependent increase in $\mathrm{p} 27^{\mathrm{Kip} 1}$ mRNA expression (Figure $6 \mathrm{~d}-$ e). On the other hand, exposure to TGF- $\beta 1$ resulted in a dose-dependent increase in de novo protein synthesis, as judged by ${ }^{3} \mathrm{H}$-proline incorporation (Figure $7 \mathrm{a}$ ). Furthermore, the incubation of HPMC with TGF- $\beta 1$ led to a timeand dose-dependent increase in fibronectin mRNA expression and release (Figure $7 \mathrm{~b}-\mathrm{d}$ ). Finally, the exposure of earlypassage cells to TGF- $\beta 1$ led to a marked dose-dependent increase in the percentage of cells expressing the marker of senescence SA- $\beta$-Gal (Figure 8a-b). After 6 days of incubation with $1 \mathrm{ng} / \mathrm{ml}$ of TGF- $\beta 1$, approximately $80 \%$ cells stained positively for SA- $\beta$-Gal, and the cultures exhibited a 3.6-fold increase in SA- $\beta$-activity (Figure 8c). Specificity of 
a

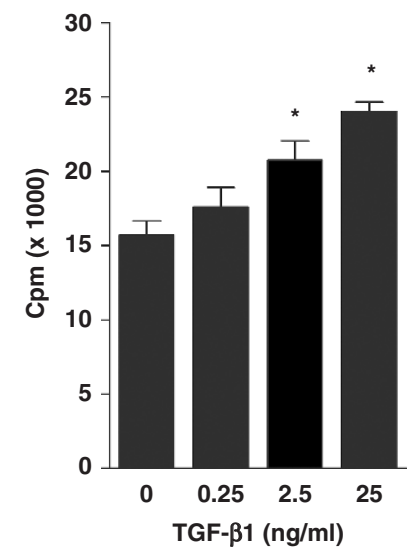

C

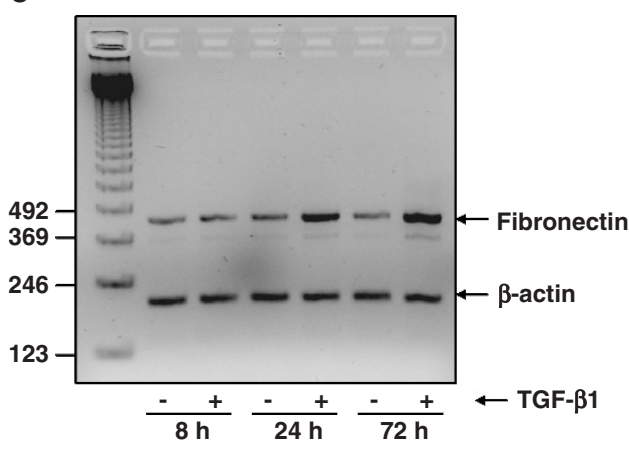

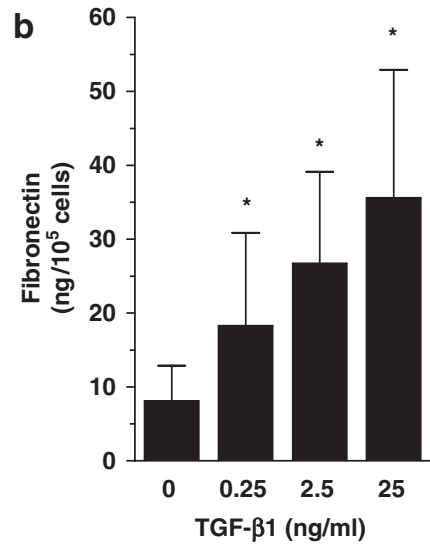

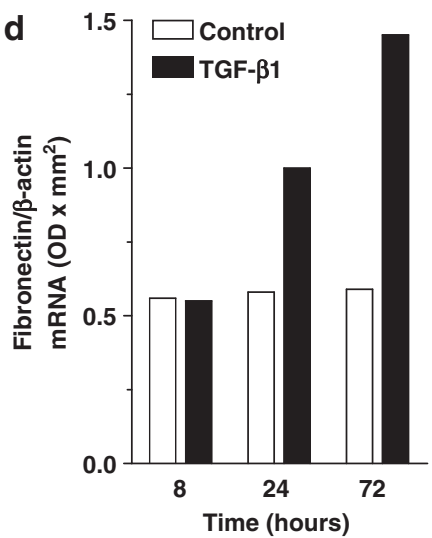

Figure 7 Effect of TGF- $\beta 1$ on protein synthesis by HPMC. (a) Early-passage cells were incubated for $48 \mathrm{~h}$ with increasing doses of TGF- $\beta 1$ and the de novo protein synthesis was assessed by ${ }^{3} \mathrm{H}$-proline incorporation. The data were derived from three independent experiments with the use of cells from different donors. Asterisks represent a significant difference compared with cells not exposed to TGF- $\beta 1$. (b) The release of fibronectin by early-passage cells stimulated with TGF- $\beta 1$ for $48 \mathrm{~h}$. The data were obtained from three experiments with cells from different donors. Asterisks represent a significant difference compared with cells not exposed to TGF- $\beta 1$. (c) Fibronectin mRNA expression in early-passage HPMC treated with $10 \mathrm{ng} / \mathrm{ml}$ of TGF- $\beta 1$ for the time-periods indicated; a representative RT-PCR experiment of two performed. (d) Densitometric fibronectin/ $\beta$-actin ratios were calculated for cells incubated in the presence $(\mathbf{\square})$ or absence $(\square)$ of TGF- $\beta 1$.

this effect was confirmed by the inhibition with anti-TGF- $\beta 1$ neutralizing antibody.

\section{Effect of Anti-TGF- $\beta 1$ Antibody on HG-Induced Increase in SA- $\beta$-Gal Activity}

Exposure of early-passage HPMC to HG for 5 days resulted in an almost three-fold increase in SA- $\beta$-Gal activity (Figure 9). This increase was partially reduced by the simultaneous addition of neutralizing anti-TGF- $\beta 1$ antibody. The inhibition was observed in eight out of nine cell lines examined, with the magnitude of inhibition ranging between 14 and $79 \%$.

\section{DISCUSSION}

Many parameters of mesothelial cell function have been used to evaluate biocompatibility of PDF. Our data indicate that the senescence response may be the next criterion to include in biocompatibility testing. Cellular senescence is viewed as a mechanism preventing the spread of potentially lethal errors to daughter cells. On the other hand, the accumulation of senescent cells may significantly alter the function of the tissue affected. ${ }^{22}$ In the present study, we have used an in vitro model of HPMC senescence ${ }^{7}$ and demonstrated that the exposure of HPMC to high concentrations of glucose resulted in the accelerated and augmented senescence response.

The inhibitory effect of glucose on HPMC proliferation has been long recognized. ${ }^{23-25}$ However, earlier studies assessed the HPMC proliferation in the short-term, up to few days, and within a period of one passage. Moreover, the cells studied were derived from early-passage populations and were cell-cycle synchronized before the exposure. ${ }^{25}$ In contrast, we have examined the growth of HPMC over their whole lifespan in culture and in the continuous presence of serum stimulation. We have observed that HPMC exposed to HG lost their proliferative potential earlier and reached fewer PD compared with control cells. Moreover, accelerated loss of HPMC proliferative capacity was associated with the increased presence of a senescence marker, SA- $\beta$-Gal. In this respect, our results are in line with those of Blazer et $a l,{ }^{26}$ who observed premature senescence of skin fibroblasts propagated 


\section{a}


b

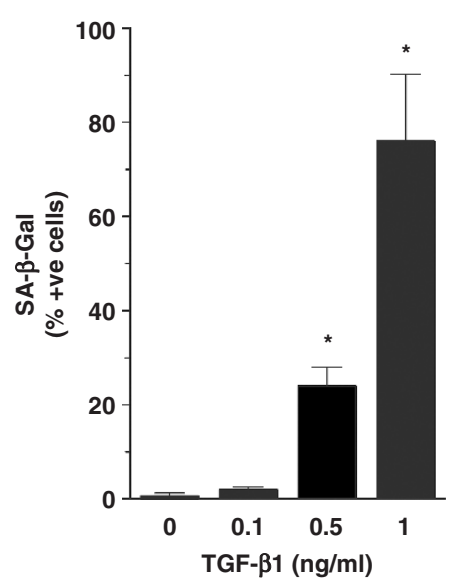

C

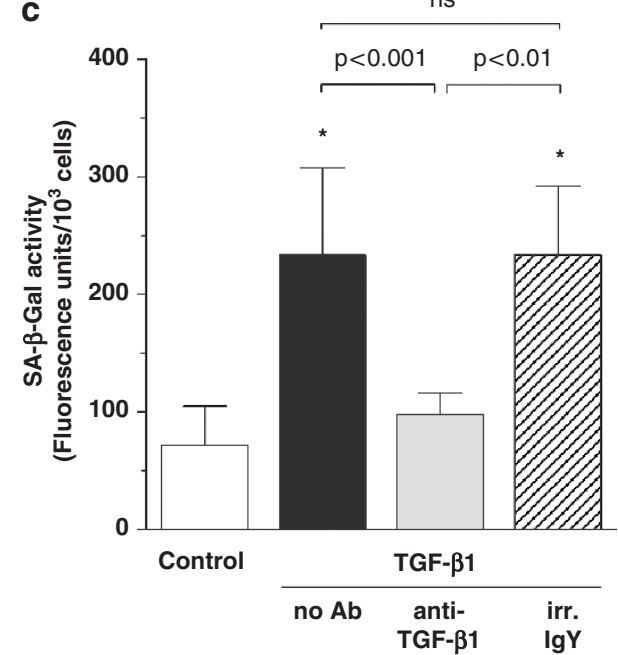

Figure 8 Effect of TGF- $\beta 1$ on the expression of SA- $\beta$-Gal in HPMC. (a) Serum-stimulated early-passage HPMC were treated with various doses of TGF- $\beta 1$ for 6 days and then analyzed for the presence of SA- $\beta$-Gal. Magnification $\times 40$. (b) Percentage of cells expressing SA- $\beta$-Gal after the incubation in the presence of absence of TGF- $\beta$ 1. The means of three independent experiments with cells from different donors. Asterisks represent a significant difference compared with cells not exposed to TGF- $\beta 1$. (c) HPMC were treated with $1 \mathrm{ng} / \mathrm{ml}$ of TGF- $\beta 1$ for 5 days in the presence of either neutralizing anti-TGF- $\beta 1$ antibody or control antibody. SA- $\beta$-Gal activity was measured in HPMC lysates by specific quantitative assay. The data represent the means of four independent experiments with cells from different donors. Asterisks represent a significant difference compared with cells not exposed to TGF- $\beta 1$.

in elevated glucose. Moreover, our results are in keeping with the observations of Gotloib et al, who detected the appearance of mesothelial cells with the senescent-like phenotype in mice treated chronically with high intraperitoneal load of glucose. ${ }^{5,27,28}$ Interestingly, both the in vivo studies and our in vitro experiments showed no significant effect of $\mathrm{M}$, which points to a specific metabolic effect of glucose, unrelated to corresponding hyperosmolality.

The peritoneal mesothelium is regarded as a slowly renewing tissue with the basal mitotic activity present in less than $1 \%$ cells. $^{27,29}$ A marked rise in mesothelial cell proliferation may occur after injury or inflammation and can be visualized by autoradiographic and cytochemical techniques. ${ }^{27,29,30}$ It has been suggested, that the periods of increased growth may lead to faster exhaustion of the proliferative capacity of HPMC. ${ }^{27}$ Indeed, the potential of the peritoneal mesothelium to replicate appears to be rather limited with cells being capable of just few rounds of mitosis, either in vivo ${ }^{27}$ or in vitro. ${ }^{7}$ In this regard, it has been ob- served that the loss of proliferative capacity in glucose-treated mesothelial cells in vivo was preceded by a short period of accelerated growth. ${ }^{27}$ We have seen a similar effect in approximately a one third of HPMC cultures exposed to HG. The lack of consistency in this respect may result from the fact, that in our setting HPMC were examined at 3-day intervals, which may be too sparse for the short-lived effect of glucose to be detected.

The process of peritoneal dialysis is associated with continuous mesothelial cell injury and regeneration. ${ }^{31}$ One may envisage a scenario, in which glucose-mediated loss of proliferative capacity will eventually hamper the repopulation of the denuded areas. Importantly, such an effect may be not seen in short-term experiments with young vigorously proliferating cells. Indeed, remesothelialization after scratch wounding in vitro was not found to be significantly affected by increased doses of glucose. ${ }^{32}$ However, it would be interesting to assess the rate of wound closure in relation to the replicative age of HPMC. 


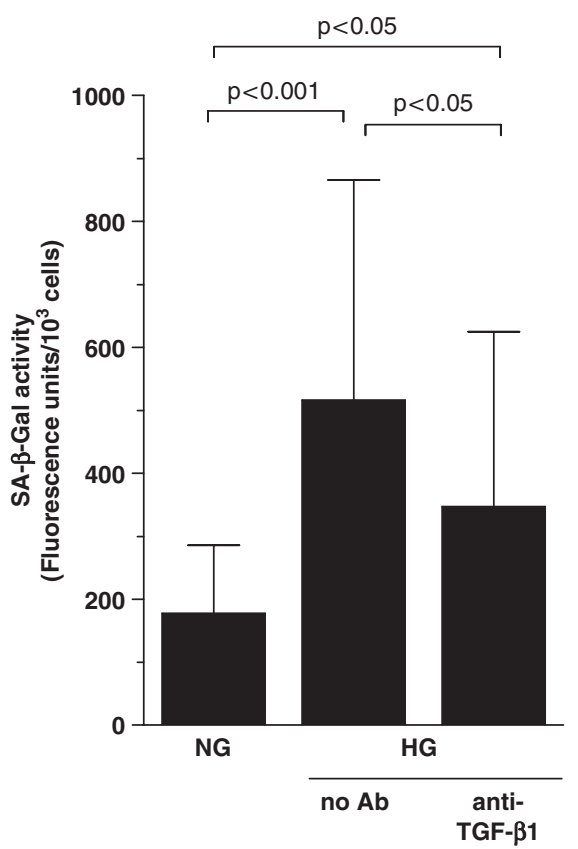

Figure 9 Effect of TGF- $\beta 1$ blockade on HG-induced increase in SA- $\beta$-Gal activity. Early-passage cells were exposed to HG for 5 days in the presence of neutralizing anti-TGF- $\beta 1$ antibody. The media were changed every 2 days. SA- $\beta$-Gal activity was measured in HPMC lysates by specific quantitative assay. The data represent the means of nine experiments with cells from seven different donors.

One of the key mediators of senescence-associated growth arrest is $\mathrm{p} 21^{\text {Wafl }}$ a cell-cycle inhibitor, activated by $\mathrm{p} 53$ protein in response to DNA damage. ${ }^{6}$ Increased expression of p $21^{\text {Wafl }}$ by HG-treated HPMC may suggest some kind of DNA injury. In this respect, Ishibashi et $a l^{33}$ detected increased presence of 8-hydroxy-2'-deoxyguanosine, a marker of oxidative DNA damage, in HPMC exposed to HG. Another inhibitor implicated in cellular senescence is $\mathrm{p} 27^{\mathrm{Kip} 1}{ }^{34}$ Indeed, we have observed an increase in $\mathrm{p} 27^{\mathrm{Kip} 1}$ expression in control HPMC undergoing senescence, and even greater increase in cells exposed to HG. Similar increases in both $\mathrm{p} 21^{\text {Waf1 }}$ and $\mathrm{p} 27^{\mathrm{Kip} 1}$ have been reported to occur in HG-treated endothelial ${ }^{35}$ and mesangial cells. ${ }^{36}$

The cessation of cell growth represents only one aspect of cellular senescence. Compared with their young predecessors, the senescent cells display marked hypertrophy and have a different profile of biosynthetic activity. We have been able to demonstrate that the exposure to HG significantly exacerbates the shift toward these features of senescence. The HG-treated HPMC became even more hypertrophic, and released more fibronectin and TGF- $\beta 1$. With the exception of fibronectin, all these effects seemed to be mediated predominantly by glucose per se rater than by hyperosmolality. Furthermore, they were not easily seen in young cells and became obvious only in late-passage cells. These observations emphasize the need for testing the cells at different phases of their lifespan. With respect to fibronectin, the stimulatory effect of glucose was, at least partly, hyperosmolality-mediated, which was not observed in earlier studies by Kumano et $a l^{37}$ and $\mathrm{Ha}$ et $a .^{38}$ However, their experiments were performed on quiescent confluent cells.

Increased expression of $\mathrm{p} 27^{\mathrm{Kip} 1}$ is believed to contribute to HG-induced cell hypertrophy. It has been demonstrated that mesangial cells deficient in $\mathrm{p} 27^{\mathrm{Kip} 1}$ did not hypertrophy in response to HG. ${ }^{39}$ In addition, the HG-stimulated increase in p2 $7^{\text {Kipl }}$ expression was found to be partly related to the increased production of TGF- $\beta 1 .{ }^{40}$ Also in our setting, HPMC undergoing senescence in the presence of elevated glucose expressed and released more TGF- $\beta 1$. Therefore, in the next series of experiments we have examined whether the senescence-associated alterations in these cells could be reproduced by the addition of exogenous TGF- $\beta 1$ to earlypassage cells maintained in low glucose medium. We have found that the exposure of HPMC to TGF- $\beta 1$ initiated the processes implicated in the pathogenesis of glucose-induced cell hypertrophy: growth inhibition, increased protein synthesis, increased $\mathrm{p} 27^{\mathrm{Kip} 1}$ expression, and enhanced fibronectin release. These results correspond to the data obtained from TGF- $\beta 1$-deficient mice. When challenged with HG, tubular epithelial cells from these animals proliferated more rapidly, and synthesized less protein and fibronectin compared with the cells from wild-type littermates. ${ }^{41}$ Finally, we have observed that the exposure of young HPMC to TGF- $\beta 1$ resulted in a rapid activation of the senescence program as judged by the presence of the biomarker SA- $\beta$-Gal. Similar induction of SA- $\beta$-gal in response to TGF- $\beta$ has been described in human lung fibroblasts ${ }^{42}$ and prostate epithelial cells. ${ }^{43}$ TGF- $\beta 1$ is known to operate in the peritoneal cavity and it has been implicated in many of the PDF-induced changes seen in CAPD patients. ${ }^{44}$ Interestingly, Gotloib et $a l^{45}$ have recently detected the increased prevalence of mesothelial cells expressing SA- $\beta$-Gal in mice exposed to polyglucose-based PDF. In order to determine directly the extent to which the effects of HG were mediated by TGF- $\beta 1$, activation of SA- $\beta$-Gal was measured in HPMC cultured in the presence anty-TGF- $\beta 1$ neutralizing antibody. The blocking capacity of this antibody was confirmed in tests with exogenous TGF- $\beta 1$. In these experiments, the anti-TGF- $\beta 1$ antibody reduced TGF- $\beta 1$-induced SA- $\beta$-Gal activation to the control level. Quantitative analysis showed that the increase in SA- $\beta$-Gal activity in early-passage cells treated with HG occurred already after few days of exposure. In this setting, the effect of TGF- $\beta 1$ blockade was less evident, approximating to $30 \%$ inhibition. This may indicate that factors other than TGF- $\beta 1$ contribute to the induction of SA- $\beta$-Gal by HG. They may include increased generation of reactive oxygen species ${ }^{46}$ or downregulation of connexin 43 gap junctions. ${ }^{36}$ Our results also suggest that at least part of TGF$\beta 1$ produced in response to HG displayed biological activity. Indeed, previous studies have documented bioactivity of HG-induced TGF- $\beta 1$. $^{35,47,48}$ 
In summary, the present study shows that chronic exposure to elevated glucose may result in the accelerated induction of senescence in HPMC in vitro, possibly through increased TGF- $\beta 1$ release. These findings could be analyzed in the context of recent observations by the Goligorsky's group: they have demonstrated that endothelial cells may undergo premature senescence when grown on glycated collagen ${ }^{49}$ and that the process is executed by the $\mathrm{p} 16^{\text {INK4a }}$ mediated pathway. ${ }^{50}$ It is now well known that peritoneal dialysis leads to glycation of peritoneal membrane proteins $^{1,51}$ and, on the other hand, the senescence of HPMC is accompanied by the upregulation of $\mathrm{p} 16^{\text {INK4a }}$. Taking all these circumstances together, one may think of looking for the evidence of premature senescence in the peritoneal membrane of patients undergoing clinical peritoneal dialysis.

1. Nakayama M, Kawaguchi $Y$, Yamada K, et al. Immunohistochemical detection of advanced glycosylation end-products in the peritoneum and its possible pathophysiological role in CAPD. Kidney Int 1997;51:182-186.

2. Di Paolo N, Sacchi G. Atlas of peritoneal histology. Perit Dial Int 2000;20(Suppl 3):S5-S96.

3. Williams JD, Craig KJ, Topley $\mathrm{N}$, et al. Morphologic changes in the peritoneal membrane of patients with renal disease. J Am Soc Nephro 2002;13:470-479.

4. Gotloib L, Waisbrut V, Shostak A, et al. Acute and long-term changes observed in imprints of mouse mesothelium exposed to glucoseenriched, lactated, buffered dialysis solutions. Nephron 1995;70: 466-477.

5. Gotloib L, Shostak A, Wajsbrot V, et al. High glucose induces a hypertrophic, senescent mesothelial cell phenotype after long in vivo exposure. Nephron 1999;82:164-173.

6. Ben Porath I, Weinberg RA. The signals and pathways activating cellular senescence. Int J Biochem Cell Biol 2005;37:961-976.

7. Ksiazek K, Piwocka K, Brzezinska A, et al. Early loss of proliferative potential of human peritoneal mesothelial cells in culture: the role of p16INK4a-mediated premature senescence. J Appl Physiol 2006;100:988-995.

8. Shankland SJ, Wolf G. Cell cycle regulatory proteins in renal disease: role in hypertrophy, proliferation, and apoptosis. Am J Physiol Renal Physiol 2000;278:F515-F529.

9. Wolf G. Cell cycle regulation in diabetic nephropathy. Kidney Int Suppl 2000;77:S59-S66.

10. Stylianou $E$, Jenner LA, Davies $M$, et al. Isolation, culture and characterization of human peritoneal mesothelial cells. Kidney Int 1990;37:1563-1570.

11. Pronk A, Leguit $P$, Hoynck van Papendrecht $A A$, et al. A cobblestone cell isolated from the human omentum: the mesothelial cell; isolation, identification, and growth characteristics. In Vitro Cell Dev Biol 1993;29A:127-134.

12. Zhang $\mathrm{XY}$, Pettengell $\mathrm{R}$, Nasiri $\mathrm{N}$, et al. Characteristics and growth patterns of human peritoneal mesothelial cells: comparison between advanced epithelial ovarian cancer and non-ovarian cancer sources. J Soc Gynecol Invest 1999;6:333-340.

13. Tremain R, Marko M, Kinnimulki V, et al. Defects in TGF-beta signaling overcome senescence of mouse keratinocytes expressing v-Ha-ras. Oncogene 2000;19:1698-1709.

14. Dimri GP, Lee $X$, Basile $G$, et al. A biomarker that identifies senescent human cells in culture and in aging skin in vivo. Proc Natl Acad Sci USA 1995;92:9363-9367.

15. Gary RK, Kindell SM. Quantitative assay of senescence-associated betagalactosidase activity in mammalian cell extracts. Anal Biochem 2005;343:329-334.

16. Witowski J, Wisniewska J, Korybalska K, et al. Prolonged exposure to glucose degradation products impairs viability and function of human peritoneal mesothelial cells. J Am Soc Nephrol 2001;12:2434-2441.
17. Jörres A, Dinter H, Topley $\mathrm{N}$, et al. Inhibition of tumour necrosis factor production in endotoxin-stimulated human mononuclear leukocytes by the prostacyclin analogue iloprost: cellular mechanisms. Cytokine 1997;9:119-125.

18. O'Bryan JP, Frye RA, Cogswell PC, et al. axl, a transforming gene isolated from primary human myeloid leukemia cells, encodes a novel receptor tyrosine kinase. Mol Cell Biol 1991;11:5016-5031.

19. Phillips AO, Steadman R, Topley N, et al. Elevated D-glucose concentrations modulate TGF-beta 1 synthesis by human cultured renal proximal tubular cells. The permissive role of platelet-derived growth factor. Am J Pathol 1995;147:362-374.

20. Phillips AO, Steadman R, Morrisey $\mathrm{K}$, et al. Exposure of human renal proximal tubular cells to glucose leads to accumulation of type IV collagen and fibronectin by decreased degradation. Kidney Int 1997;52:973-984.

21. Ye $L$, Zhang HY, Wang $H$, et al. Effects of transforming growth factor beta 1 on the growth of rhabdomyosarcoma cell line RD. Chin Med J (England) 2005;118:678-686.

22. Campisi J. Senescent cells, tumor suppression, and organismal aging: good citizens, bad neighbors. Cell 2005;120:513-522.

23. Breborowicz A, Rodela H, Oreopoulos DG. Toxicity of osmotic solutes on human mesothelial cells in vitro. Kidney Int 1992;41:1280-1285.

24. Witowski J, Knapowski J. Glycerol toxicity for human peritoneal mesothelial cells in culture: comparison with glucose. Int J Artif Organs 1994;17:252-260.

25. Chan TM, Leung JK, Sun Y, et al. Different effects of amino acid-based and glucose-based dialysate from peritoneal dialysis patients on mesothelial cell ultrastructure and function. Nephrol Dial Transplant 2003;18:1086-1094.

26. Blazer S, Khankin E, Segev $Y$, et al. High glucose-induced replicative senescence: point of no return and effect of telomerase. Biochem Biophys Res Commun 2002;296:93-101.

27. Shostak A, Wajsbrot V, Gotloib L. High glucose accelerates the life cycle of the in vivo exposed mesothelium. Kidney Int 2000;58: 2044-2052.

28. Gotloib L, Wajsbrot V, Shostak A, et al. Effect of hyperosmolality upon the mesothelial monolayer exposed in vivo and in situ to a mannitolenriched dialysis solution. Nephron 1999;81:301-309.

29. Mutsaers SE, Whitaker D, Papadimitriou JM. Mesothelial regeneration is not dependent on subserosal cells. J Pathol 2000;190:86-92.

30. Mutsaers SE, Whitaker D, Papadimitriou JM. Stimulation of mesothelial cell proliferation by exudate macrophages enhances serosal wound healing in a murine model. Am J Pathol 2002;160: 681-692.

31. Gotloib L, Shostack A, Bar Sella P, et al. Continuous mesothelial injury and regeneration during long term peritoneal dialysis. Perit Dial Int 1987;7:148-155.

32. Morgan LW, Wieslander A, Davies M, et al. Glucose degradation products (GDP) retard remesothelialization independently of d-glucose concentration. Kidney Int 2003;64:1854-1866.

33. Ishibashi $Y$, Sugimoto $T$, Ichikawa $Y$, et al. Glucose dialysate induces mitochondrial DNA damage in peritoneal mesothelial cells. Perit Dial Int 2002;22:11-21.

34. Bringold F, Serrano M. Tumor suppressors and oncogenes in cellular senescence. Exp Gerontol 2000;35:317-329.

35. McGinn S, Poronnik $P$, King $M$, et al. High glucose and endothelial cell growth: novel effects independent of autocrine TGF-beta 1 and hyperosmolarity. Am J Physiol Cell Physiol 2003;284:C1374-C1386.

36. Zhang X, Chen X, Wu D, et al. Downregulation of connexin 43 expression by high glucose induces senescence in glomerular mesangial cells. J Am Soc Nephrol 2006;17:1532-1542.

37. Kumano K, Schiller B, Hjelle JT, et al. Effects of osmotic solutes on fibronectin mRNA expression in rat peritoneal mesothelial cells. Blood Purif 1996;14:165-169.

38. $\mathrm{Ha} \mathrm{H}, \mathrm{Yu}$ MR, Lee HB. High glucose-induced PKC activation mediates TGF-beta 1 and fibronectin synthesis by peritoneal mesothelial cells. Kidney Int 2001;59:463-470.

39. Wolf G, Schroeder R, Zahner G, et al. High glucose-induced hypertrophy of mesangial cells requires p27(Kip1), an inhibitor of cyclin-dependent kinases. Am J Pathol 2001;158:1091-1100.

40. Wolf G, Schroeder R, Ziyadeh FN, et al. High glucose stimulates expression of p27Kip1 in cultured mouse mesangial cells: relationship to hypertrophy. Am J Physiol 1997;273:F348-F356. 
41. Chen S, Hoffman BB, Lee JS, et al. Cultured tubule cells from TGF-beta1 null mice exhibit impaired hypertrophy and fibronectin expression in high glucose. Kidney Int 2004;65:1191-1204.

42. Frippiat C, Chen QM, Zdanov S, et al. Subcytotoxic $\mathrm{H} 2 \mathrm{O} 2$ stress triggers a release of transforming growth factor-beta 1, which induces biomarkers of cellular senescence of human diploid fibroblasts. J Biol Chem 2001;276:2531-2537.

43. Untergasser G, Gander R, Rumpold H, et al. TGF-beta cytokines increase senescence-associated beta-galactosidase activity in human prostate basal cells by supporting differentiation processes, but not cellular senescence. Exp Gerontol 2003;38: 1179-1188.

44. Margetts PJ, Oh KH, Kolb M. Transforming growth factor-beta: importance in long-term peritoneal membrane changes. Perit Dial Int 2005;25(Suppl 3):S15-S17.

45. Gotloib L, Wajsbrot V, Shostak A. Icodextrin-induced lipid peroxidation disrupts the mesothelial cell cycle engine. Free Radic Biol Med 2003;34:419-428.
46. Passos JF, von Zglinicki T. Oxygen free radicals in cell senescence: are they signal transducers? Free Radic Res 2006;40:1277-1283.

47. Rocco MV, Chen Y, Goldfarb S, et al. Elevated glucose stimulates TGFbeta gene expression and bioactivity in proximal tubule. Kidney Int 1992:41:107-114.

48. Khera T, Martin J, Riley S, et al. Glucose enhances mesangial cell apoptosis. Lab Invest 2006;86:566-577.

49. Chen J, Brodsky SV, Goligorsky DM, et al. Glycated collagen I induces premature senescence-like phenotypic changes in endothelial cells. Circ Res 2002;90:1290-1298.

50. Chen J, Huang X, Halicka D, et al. Contribution of p16INK4a and p21CIP1 pathways to induction of premature senescence of human endothelial cells: permissive role of p53. Am J Physiol Heart Circ Physiol 2006;290:H1575-H1586.

51. Honda K, Nitta K, Horita S, et al. Accumulation of advanced glycation end products in the peritoneal vasculature of continuous ambulatory peritoneal dialysis patients with low ultra-filtration. Nephrol Dia Transplant 1999;14:1541-1549. 